\title{
ACCRUAL ACCOUNTING, FOUNDATION FOR THE FINANCIAL REPORTING INTO THE PUBLIC SECTOR ENTITIES
}

\author{
Aurelia Ştefănescu ${ }^{1}$ \\ Eugeniu Țurlea ${ }^{2}$
}

\begin{abstract}
The development of the accounting system of the public sector entities at mondial level has focused on taking up the accrual accounting as foundation for the financial reporting and totally or partially giving up the cash accounting. Within this context, by this research, we define the coordinates of the accrual accounting, we analyse the adoption of it as a financial reporting basis into the public sector at international level and also the implications of completing the cash accounting with the accrual accounting into the Romanian public sector. The research takes into consideration a synthesis of the ideas published upon this topic into the professional literature, the regulations issued by the national and international accounting regulators, by accounting bodies.
\end{abstract}

Key words: public sector entity, accrual accounting, financial reporting, International Public Sector Accounting Standards (IPSAS)

JEL codes:M 41, H 83

\section{Introduction}

In accordance with the International Public Sector Accounting Standards (IPSAS 1 Display of the financial statements), the declared objective of the financial statements is to offer information on the financial position, financial performance and treasury flows of an entity, useful for a wide range of users in making and assessing the decisions related to resource allocation. Thus, an important role is given to the financial reporting basis, respectively the accrual accounting or/and cash accounting. Having as a premise the adoption of the accrual accounting into the public sector as a consequence of the implementation of the New Public Financial Management, we define the accrual accounting and identify the manners of adopting it as the basis of financial reporting at national and international level.

\section{Research methodology}

The undertaken research has as objective to explain the concept of accrual accounting and to emphasize the manner in which this has been adopted as financial reporting basis into the national and international public sector.

The research takes into consideration a synthesis of the ideas published upon this topic into the professional literature, the regulations issued by the national and international accounting regulators, by accounting bodies.

To achieve the proposed objective, a fundamental research methodology has been used. Also, there have been used deductive and inductive mechanisms of research to delimit the concept of accrual accounting, the comparative analysis of the manner of adopting the accrual accounting at international level, as well as into the public sector from Romania.

\footnotetext{
${ }^{1}$ The Academy of Economic Studies, Bucharest, Romania, e-mail: stefanescu.aura@gmail.com

${ }^{2}$ The Academy of Economic Studies, Bucharest, Romania,e-mail: eturlea@yahoo.com
} 


\section{Conceptual assertions on the accrual accounting into the public sector}

In terms of the accounting classical view, the accrual accounting is the accounting basis according to which the accounting elements are recognized on their appearance, regardless of the moment of cashing/paying the monetary means or other form of compensation (http://www.econtabilitate.md/dictionar-contabil).

With reference to the public sector, in terms of the International Public Sector Accounting Standards (IPSAS), the accrual accounting, called accrual basis, is an accounting principle according to which the transactions and events are recognized when they occur, and not when they materialize into cash or cash equivalents received or paid. Thus, transactions and events are registered into the books of account and recognized into the financial statements related to the periods they refer to. The elements recognized according to this reporting basis are the assets, debts, capital equity, revenues and expenses.

The national regulations, inspired from the International Public Sector Accounting Standards, have agreed the name of the principle of accrual accounting according to which the effects of the transactions and other events are recognized when the transactions and events occur, and not when the cash or its equivalent is collected or paid and they are registered into the books of account and reported into the financial statements related to the periods of reporting. By adopting the accrual accounting as financial reporting basis, the financial statements disseminate information not only on the past transactions and events determining collections and payments, but also on the future resources, future payment liabilities.

In Dupuis' view (2004), the accrual accounting is founded on the principle of reconciliation that measures all the revenues gained during a given period and all the expenses engaged for obtaining them. In this respect, the revenues are assigned to the period when they have been obtained, and the expenses are calculated in respect of the goods and services used for obtaining the revenues.

In another approach, Lande (2008) considers that the adoption of the accrual accounting introduces a patrimony view, due to the fact it connects the expenses and revenues of the financial year in accordance with the generator fact and it also presents the assets and shareholders equity + liabilities.

The definition of the accrual accounting into the public sector given by Biondi (2008) is substantiated by the identification of the accounting models which describe the activity of the economic entities from the private sector, i.e. the patrimony model, the financial model and the economic model. The patrimony model (static) is focused on the held net resources and their assessment at a given time. The financial model is focused on the available resources to sustain the on-going activity. The economic model (dynamic) is focused on the mobilized (and consumed) resources during the activity of the entity. The author estimates that the dynamic accounting model corresponds to the accrual accounting and answers the public sector characteristics, due to the fact that it is focused on expenses and revenues and it allows the improvement of the cost calculations and the supply of information with reference to the economy and public finance.

The review of the approaches of the accrual accounting concept points out their interference and the fact they are focused on the following elements: expenses, revenues, moment of getting the revenues/recognizing the expenses, financial reporting.

\section{disparity?}

Accrual accounting, financial reporting basis into the public sector - unity or

In most of the public sector entities at international level the accrual accounting is adopted as financial reporting basis. The adoption process of the accrual accounting is different in terms of the adoption schedule, adoption manner and scope. In this respect, the professional literature searches have shown that the Anglo-Saxon countries are the first to adopt the accrual accounting as a result of the interest into the reform of the accounting system from the public sector. In respect of 
the accrual accounting adoption manner, this has had as basis either the national regulations, or the adoption of the International Public Sector Accounting Standards (IPSAS). With reference to the scope, in some countries, the option of adopting the accrual accounting belongs to the local public sector, respectively, central public sector, in accordance with the personal needs; in other countries, the accrual accounting has been adopted first into the local public sector and then developed also at central level, either simultaneously for both sectors, or adopted according to the typology of the public sector.

In this respect, Carvalho et al (2007) argue that although the accrual accounting has been implementaed at international level, the systems of financial information into the public sector are divergent. A similar idea is supported by Christiaens et al (2010) who consider that each country adopts the accrual accounting into the public sector in accordance with its needs of information, determining a disparity of the reforms based on the accrual accounting. In this respect the authors investigated in 2008 the manner of adopting the accrual accounting into the financial reporting, in 17 of the European Union countries. The results of the study pointed out the following (Table no.1):

$>$ France, Lithuania, Sweden, Switzerland and Great Britain have adopted the accrual accounting into the central public sector by relatively applying the International Public Sector Accounting Standards (IPSAS), whereas Austria, Denmark, Portugal, Spain have adopted the accrual accounting although they do not apply IPSAS;

Into the local public sector from Belgium, Lithuania, Sweden and Great Britain the accrual accounting is adopted as financial reporting basis through the effect of adopting IPSAS. In opposition there come the local public sectors from Denmark, Finland, France, the Netherlands, Norway, Portugal, Spain, Switzerland and Wallonia reporting on the basis of the accrual accounting, but they have not chosen IPSAS;

Belgium, Italy and Wallonia apply the cash accounting for the financial reporting into the central public sector, but they consider the adoption of the accrual accounting;

The local public sector entities from BadenWürttemberg, Greece, Italy, Sachsen-Anhaltsen use cash accounting for the financial reporting, but they forecast introducing the accrual accounting;

The central public sectors from BadenWürttembele, Bavaria, Greece, Sachsen-Anhaltsen and the local ones from Austria and Bavaria apply cash accounting and they do not forecast adopting the accrual accounting for the financial reporting.

Adoption of the accrual accounting as financial reporting basis

Table no. 1

\begin{tabular}{|c|c|c|c|c|c|c|c|c|c|c|}
\hline \multirow[t]{3}{*}{$\begin{array}{l}\text { Countries/ } \\
\text { Jurisdictions }\end{array}$} & \multicolumn{2}{|c|}{$\begin{array}{l}\text { Apply } \\
\text { IPSAS }\end{array}$} & \multirow{2}{*}{\multicolumn{2}{|c|}{$\begin{array}{l}\text { Reforms for } \\
\text { adopting } \\
\text { IPSAS }\end{array}$}} & \multicolumn{2}{|c|}{$\begin{array}{l}\text { Apply accrual } \\
\text { accounting }\end{array}$} & \multicolumn{2}{|c|}{$\begin{array}{l}\text { Reforms for } \\
\text { adopting } \\
\text { accrual } \\
\text { accounting } \\
\end{array}$} & \multicolumn{2}{|c|}{$\begin{array}{c}\text { Apply } \\
\text { Cash accounting }\end{array}$} \\
\hline & \multicolumn{8}{|c|}{ Public Sector } & & \\
\hline & Central & Local & Central & Local & Central & Local & Central & Local & Central & Local \\
\hline Austria & - & - & - & - & Yes & - & - & - & - & Yes \\
\hline $\begin{array}{l}\text { Baden } \\
\text { Württemberg } \\
\text { (Germany) }\end{array}$ & - & - & - & - & - & - & - & Yes & Yes & - \\
\hline $\begin{array}{l}\text { Bavaria } \\
\text { (Germany) }\end{array}$ & - & - & - & - & - & - & - & - & Yes & Yes \\
\hline Denmark & - & - & - & - & Yes & Yes & - & & - & - \\
\hline Finland & - & - & - & - & Yes & Yes & - & - & - & - \\
\hline Belgium & - & Yes & - & - & - & - & Yes & - & - & - \\
\hline France & Yes & - & - & - & - & Yes & - & - & - & - \\
\hline Greece & - & - & - & - & - & - & - & Yes & Yes & - \\
\hline Italy & - & - & - & - & - & - & Yes & Yes & - & - \\
\hline
\end{tabular}




\begin{tabular}{|l|c|c|c|c|c|c|c|c|c|c|}
\hline Lithuania & Yes & Yes & - & - & - & - & - & - & - & - \\
\hline $\begin{array}{l}\text { The } \\
\text { Netherlands }\end{array}$ & - & - & Yes & - & - & Yes & - & - & - & - \\
\hline Norway & - & - & Yes & - & - & Yes & - & - & - & - \\
\hline Portugal & - & - & - & - & Yes & Yes & - & - & - & - \\
\hline $\begin{array}{l}\text { Sachsen- } \\
\begin{array}{l}\text { Anhaltsen } \\
\text { Germany) }\end{array}\end{array}$ & - & - & - & - & - & - & - & Yes & Yes & - \\
\hline Spain & - & - & - & - & Yes & Yes & - & - & - & - \\
\hline Sweden & Yes & Yes & - & - & - & - & - & - & - & - \\
\hline Switzerland & Yes & - & - & - & - & Yes & - & - & - & - \\
\hline Great Britain & Yes & Yes & - & - & - & - & - & - & - & \\
\hline $\begin{array}{l}\text { Wallonia } \\
\text { (Belgium) }\end{array}$ & - & - & - & - & - & Yes & - & - & Yes & - \\
\hline
\end{tabular}

Source: Christiaens, J., Reyniers, B., Rollé, C., Les conséquences des IPSAS sur la réforme des systèmes d'information financière publique: étude comparative, Revue Internationale des Sciences Administratives, nr.3/2010 Vol. 76, pg. 571-572

Another argument in favor of the disparity of the accrual accounting adoption into the public sector is the study performed by the IFAC Committee for the Professional Accountants in Business (2008) into the public sector entities at all the governmental levels from various sectors in 41 countries (Table no 2):

Table no.2

\section{The primary basis of financial reporting}

\begin{tabular}{|c|c|c|c|}
\hline \multirow[t]{2}{*}{ Typology of public sector } & \multicolumn{3}{|c|}{ Basis of financial reporting } \\
\hline & Cash (\%) & Accrual (\%) & Other (\%) \\
\hline General public services & 18,7 & 73,3 & 8,0 \\
\hline Defense & 12,5 & 87,5 & 0,0 \\
\hline Public Order and Safety & 18,2 & 72,7 & 9,1 \\
\hline Economic affairs & 13,0 & 82,6 & 4,3 \\
\hline Environmental protection & 0,0 & 83,3 & 16,7 \\
\hline Housing and community & 20,0 & 80,0 & 0,0 \\
\hline Health & 9,7 & 90,3 & 90,3 \\
\hline Recreation, culture, religion & 50,0 & 50,0 & 50,0 \\
\hline Education & 10,8 & 83,8 & 83,8 \\
\hline Social protection & 20,0 & 80,0 & 0,0 \\
\hline Other & 20,0 & 70,0 & 10,0 \\
\hline Total respondents & 15,6 & 79,1 & 10 \\
\hline \multicolumn{4}{|l|}{ Countries* / Reporting basis } \\
\hline Australia & 5,6 & 88,9 & 5,6 \\
\hline Canada & 8,3 & 83,3 & 8,3 \\
\hline The Netherlands & 22,2 & 66,7 & 11,1 \\
\hline Pakistan & 18,2 & 81,8 & 0,0 \\
\hline United Kingdom & 6,3 & 92,7 & 1,0 \\
\hline USA & 16,7 & 66.7 & 16,7 \\
\hline Other countries & 16,7 & 66,7 & 16,7 \\
\hline NON United Kingdom & 22,5 & 69,0 & 9,5 \\
\hline Total respondents & 15,6 & 79,1 & 10 \\
\hline
\end{tabular}

Source: IFAC(2008)Developments in Performance Measurement Structures in Public Sector Entities,

pg.51, available at http://www.ifac.org/sites/default/files/publications/files/Developments\%20in\%

20 Performance\% 20 Measurement\%20Structures\%20in\%20Public\%20Sector\%20Entities.pdf

* There were chosen in accordance with the number of respondents 
The results of the survey show that the adoption of the accrual accounting into the financial reporting is different according to the typology of the public sector: general public services, defense, public order and safety, economic affairs, environmental protection, housing and community, health, recreation, culture, religion, education, social protection, others. Also, we notice the fact that the public sector using prevailingly the accrual accounting into the financial reporting is the healthcare one $(90,3 \%)$, and the country with the highest applicability of the accrual accounting is Great Britain (92,7\%). In respect of the extent to which the accrual accounting is used as financial reporting basis, in comparison with the cash accounting or other reporting basis, there can be noticed that the accrual accounting prevails regardless of the typology of the public sector and the country.

The disparity of adopting the accrual accounting into the public sector is also proved by the case of France. Founding European Union member since 1958, France started the process of including into the public sector the new accounting having as basis the International Public Sector Accounting Standards (IPSAS) in 2001, as a result of the provisions of the public finance law (LOLF), but the adoption of the accrual accounting has been circumscribed to the global reform of the modernization of the public management since 2004. Adoption of the accrual accounting is the consequence of the national regulations which resemble from point of view of contents to the International Public Sector Accounting Standards (IPSAS), but they are more elementary and easier to apply (Robert\&Colibert, 2008). Another feature is the fact that the application of the accounting regulations is circumscribed to the typology of the French public sector, respectively state, social safety and local sector.

Into the Romanian public sector, regardless of its typology, the accrual accounting was adopted as financial reporting basis in 2005 through the national accounting regulations (Order of the minister of public finance no. 1917/2005 for the adoption of the Methodological regulations on the accounting organization and management of the public entities, Plan of accounts for the public entities and its application instructions). This option has been circumscribed to the programme of accounting development of the public sector entities as a result of Romania's taking strategy of adhesion to the status of full European Union member. In comparison with other mamber states of the European Union, the manner of adopting the accrual accounting is the one of completing the cash accounting. In reality, the financial reporting into the public sector has as basis the combination of cash accounting and accrual accounting. Although the fundamental components of the set of financial statements (Balance Sheet, the account of patrimony earned income, the situation of modifications within the structure of assets / shareholders equity + liabilities) are obviously drawn on the basis of the accrual accounting, the inclusion into the set of financial statements of the budgetary execution account by the accounting regulators (based on the cash accounting) generates confusions and wrongly inclines the users' interest towards the information reported on the basis of cash accounting.

\section{Conclusions}

This research emphasizes the fact that the adoption of the accrual accounting as financial reporting basis is predominant into the public sector at international, European and national levels.

Also, there can be noticed the fact that the process of adopting the accrual accounting is heterogeneous in respect of the adoption period, regulations/deregulations to which it is circumscribed, as well as the typology of the public sector. In our opinion, this disparity is the consequence of the existing cultural, juridical, administrative-territorial differences between the countries, of the various stages of development of their economies and of the multiple features of the public sector. The unity is given by the application on a large scale of the accrual accounting within the financial reporting of the public sector from the entire world.

In our opinion, the disparity of adopting the accrual accounting within the financial reporting of the public sector does not limit the objective of the financial reporting given by the international 
accounting references i.e. to offer useful information to adopt the decisions and demonstrate the responsibility of the entity for the given resources. An argument in this direction is given by the absolute advantages of applying the accrual accounting into the financial reporting. Out of these we point out the following: it cuts out confusions regarding the financial communication with the users; it promotes financial transparency; it offers an exhaustive image of the assets, debts, capital equity; it allows measuring the cost of goods and services; it offers forecast information on the resources and obligations; it allows a better monitoring and more efficient control of expenses; it introduces the management through earned incomes; it promotes social responsibility.

\section{Acknowledgement}

This work was supported by CNCSIS-UEFISCDI, project no.955/19.01.2009 PNII - IDEI, code ID_1827/2008, Panopticon on the performance connotations in the public sector entities in Romania - creation versus dissemination

\section{References}

1. Biondi Y., 2008. De Charybde de la comptabilité de caisse en Scylla de la comptabilité patrimoniale, Revue de la régulation [En ligne], nr.3/4, semester 2, pp.1-11, available at $\mathrm{http} / / /$ regulation.revues.org/index5003.html, accessed on the date of 10.11.2009

2. Carvalho J., Jorge S., Fernandes M., 2007. Conformity and Diversity of Accounting and Financial Reporting Practices in Portuguese Local Government, Canadian Journal of Administrative Sciences 24(1), pp. 2-14

3. Christiaens J., Reyniers B., Rollé C., 2010. Les conséquences des IPSAS sur la réforme des systèmes d'information financière publique: étude comparative, Revue Internationale des Sciences Administratives, no.3/2010 Vol. 76, pp. 563-581, available at http://www.cairn.info/revue-internationale-des-sciences-administratives-2010-3-page563.htm, accessed on the date of 07.09.2011

4. Dascălu C., Nişulescu I., Caraiani C., Ştefănescu A., Pitulice C., 2006. Convergence of the Romanian public accounting to the International Public Sector Accounting Standards, CECCAR Publishing House, Bucharest

5. Dupuis J., 2004. La comptabilité d'exercice integralé, available at http://dsppsd.pwgsc.gc.Ca/ Collection-R/LoPBdP/PRB-f/PRB0404-f.pdf, accessed on the date of 30.10.2010, pp.4

6. Lande E., 2008. Reforme comptable et performance, L'importance des systèmes de contrôle dans la réussite des réformes comptables des États, Colloque, 18-19 September 2008, France, pp. 4

7. Mattret J.B., 2010. La nouvelle compatbilité publique, L.G.D.J Publishing House, Paris

8. Robert, F., R., Colibert, J. 2008, Les normes IPSAS et le secteur public, Dunod Publishing House, Paris, pp. 250-252

9. Accounting dictionary, available at http://www.e-contabilitate.md/dictionar-contabil, accessed on the date of 07.09.2011

10. IFAC, 2009. Manual of International Public Sector Accounting Standards, vol. I, II, translation, CECCAR Publishing House, Bucharest

11. IFAC, 2008. Developments in Performance Measurement Structures in Public Sector Entities, 2008, pg.51, available at http://www.ifac.org/sites/default/files/publications /files/ Developments\%20in\%20Performance $\% 20$ Measurement $\% 20$ Structures $\% 20$ in $\% 20$ Public $\% 2$ 0 Sector \%20Entities.pdf, accessed on the date of 06.09.2011

12. Ministry of Public Finance, Order of the Minister of Public Finance no. 1917/2005 for the adoption of the Methodological regulations on the accounting organization and management of the public entities, Plan of accounts for the public entities and its application instructions, published into the Romanian Official Monitory no. 1.18 bis on 29.12.2005 